\title{
INSPIREE:
}

\section{Evaluation of Reaction Time on Karate Athletes UKM Syiah Kuala University}

doi https://doi.org/10.53905/inspiree.v3i01.74

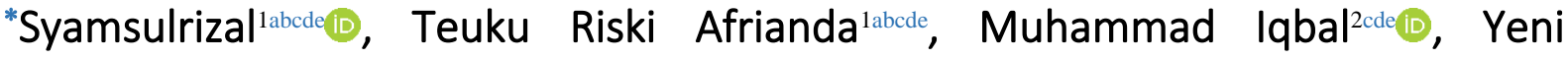 \\ Marlina ${ }^{\text {labcde, }}$ Zahara ${ }^{\text {labcde }}$
}

${ }^{1}$ Departement of Physical, Health and Recreation Education, Faculty of Teacher Training and Education, University of Syiah Kuala. Indonesia.

${ }^{2}$ Department of Physical Education and Sport, STKIP Kusumanegara Jakarta, Indonesia.

\begin{abstract}
The purpose of the study. Reaction time is a determining factor in sports, especially in martial arts. The purpose of this study is to evaluate the reaction time of UKM Karate athletes at Syiah Kuala University.

Materials and methods. The approach in this study uses a quantitative approach. The sampling technique used purposive sampling, which means this technique is used to achieve certain goals. The samples in this study were athletes from UKM karate at Syiah Kuala University. The data collection technique was carried out by using the whole body reaction test to measure the reaction time of the athlete's arms and legs.

Results. results of the research in the form of a whole body reaction test, the results using the formula for the average value and the total percentage can be concluded: (1) The arm reaction time test with the total average value for male athletes is 0.169 seconds and female athletes are 0.173 , and the highest percentage is in the very good category, amounting to $87 \%$ for male and female athletes, $75 \%$ in the very good category and (2) the limb reaction time test has an average value of 0.269 seconds for male athletes and female athletes of 0.361 seconds, with the highest percentage value amounted to $100 \%$ in the good category for male athletes and for female athletes it was in the sufficient category with a percentage of $50 \%$.

Conclusions. the analysis show that most athletes have been able to maintain and increase reaction time well, to be able to improve and maintain it, regular and continuous training is needed.
\end{abstract}

ARTICLE I NFO

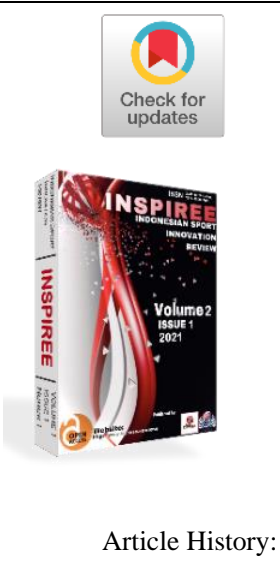

Received: November 10, 2021 Accepted: December 26, 2021

Published: January 27, 2022

Keywords: reaction time; karate athlete.

\section{INTRODUCTION}

Karate is one of the branches of martial arts that is developing in Aceh, in karate sports it is also necessary to train some elements of physical conditions, such as the reaction time of the limbs, and hands, in this case the reaction time of the legs and hands in karate is something that must be very important. every athlete has, because without leg reaction time, and good hands it will be difficult for an athlete to master a match, with leg reaction time and good hands an athlete will be able to take advantage 
Evaluation of Reaction Time on Karate Athletes UKM Syiah Kuala University

of opportunities to get points, not only that with the speed of reaction of the legs, and good hands an athlete is able to block or can avoid the opponent's attack and if possible can return to attack the opponent with a punch or kick (Nauta et al).

A karate athlete needs reaction time, because by having a good reaction time, both kicking and hitting speed, it is very easy for an athlete to be able to steal points from an opponent so that he can win a match, speed must also be accompanied by good physical conditions. good because if an athlete does not have a good physical condition then it is difficult for him to be able to excel, as well as what must be needed by UKM karate athletes at Syiah Kuala University (Creswell, 2002).

UKM is a Student Activity Unit which is a place for students to express their talents so that they can be developed again based on the field they are engaged in. According to Siswanto (Qualitative Inquiry and Research Design) "organization can be defined as a group of people who interact and work together to realize certain goals. The Student Activity Unit (UKM) is a forum for students to organize in various fields of activity, one of which is sports. Unsyiah Karate UKM was established with the intention of coordinating and carrying out coaching in the form of karate martial arts sports activities, developing and improving the quality and achievements of student karate athletes within the Syiah Kuala University.(Using International Accreditation in Higher Education to Effect Changes in Organisational Culture: A Case Study from a Turkish University-Ian Collins, 2015, n.d.) UKM Karate Athletes at Syiah Kuala University already have experience competing both at the regional and national levels. Reaction time is very influential in karate, by having a good arm and leg reaction time it is very easy for an athlete to win a match, as well as a karate athlete at Syiah Kuala University must have. By having a good reaction time it is very easy for them to dodge and attack in a match.

\section{MATERIALS AND METHODS}

\section{Study Participants}

The population in this study was the entire Unsyiah Karate UKM athlete in 2020, namely 47 students. The sample is representative of the population. The sampling technique in this research is purposive sampling. According to(Botanists of the TwentyFirst Century, n.d.) "purposive sampling is a sampling technique with certain considerations. The criteria for determining this sample include: (1) athletes who are 
Evaluation of Reaction Time on Karate Athletes UKM Syiah Kuala University

still actively exercising, (2) present at the time of the study, and (3) male and female.

Based on these criteria, the sample in this study amounted to 12.

\section{Study Organization}

Approach in this study using a quantitative approach. Because the data collected is based on the information provided by the respondent, so the data obtained is analyzed by researchers based on numerical units.(Hendra, n.d.) The type of this research is descriptive research, in this case (Sugiyono, n.d.) says that: Descriptive research studies problems in society and certain situations such as activities, attitudes, views and processes that take place as well as the influence of certain phenomena.

\section{Testing Procedure}

Data collection techniques in this study were in the form of test items using whole body reaction time to measure the reaction time of the arms and legs.

\section{RESULTS}

Table 1. Recapitulation of Raw Data Results of Arm Reaction time Test on Male Karate Athletes at UKM Syiah Kuala University.

\begin{tabular}{lc}
\hline Sample (Male) & Result (Second) \\
\hline 1 & 0,190 \\
2 & 0,148 \\
3 & 0.153 \\
4 & 0.162 \\
5 & 0,162 \\
6 & 0,203 \\
7 & 0,200 \\
8 & 0,141 \\
\hline Total & $\mathbf{1 , 3 5 9}$ \\
\hline
\end{tabular}

Table 2. Recapitulation of Raw Data Results of Arm Reaction time Test on Female Karate Athletes at UKM Syiah Kuala University.

\begin{tabular}{|c|c|}
\hline Sample (Female) & Result (Second) \\
\hline 1 & 0,159 \\
\hline 2 & 0,154 \\
\hline 3 & 0,206 \\
\hline 4 & 0,174 \\
\hline Total & 0,693 \\
\hline
\end{tabular}

Table 3. Recapitulation of Raw Data Result of Leg Reaction time Test on Male Karate Athletes of UKM Syiah Kuala University.

\begin{tabular}{|c|c|}
\hline Sample (Male) & Result (Second) \\
\hline 1 & 0,275 \\
\hline 2 & 0,214 \\
\hline 3 & 0,309 \\
\hline 4 & 0,286 \\
\hline 5 & 0,264 \\
\hline 6 & 0,258 \\
\hline 7 & 0,296 \\
\hline 8 & 0,256 \\
\hline Total & 2,158 \\
\hline
\end{tabular}

Table 4. Raw Data Recapitulation of Leg Reaction Test Results at UKM Male Karate Female Athletes at Syiah Kuala University.

\begin{tabular}{lc}
\hline Sample Female & Result (Second) \\
\hline 1 & 0,265 \\
2 & 0,363 \\
3 & 0,465
\end{tabular}


Research Data Analysis Calculating Average Score

\begin{tabular}{|c|c|}
\hline \multicolumn{2}{|c|}{ Arm Reaction time } \\
\hline $\begin{array}{l}\text { Man Atlet } \\
1,359\end{array}$ & $\begin{array}{l}\text { Female Atlet } \\
0.693\end{array}$ \\
\hline$=\frac{8}{8}$ & $=\frac{0,000}{4}$ \\
\hline$=0,169$ Second & $=0,173$ Second \\
\hline \multicolumn{2}{|c|}{ Limb Reaction time } \\
\hline $\begin{array}{c}\text { Man Atlet } \\
2,158\end{array}$ & $\begin{array}{l}\text { Female Atlet } \\
-1,447\end{array}$ \\
\hline$=\frac{8}{8}$ & $=\frac{-4}{4}$ \\
\hline$=0,269$ second & $=0,361$ second \\
\hline
\end{tabular}

\section{Calculating Percentage Value}

Table 5. Percentage of Arm Reaction time of Male Karate Athletes of UKM Syiah Kuala University.

\begin{tabular}{lllcc}
\hline No & & Kategori & Frekuensi & Persentase \\
\hline 1 & Special & & 0 & $0 \%$ \\
2 & Very good & & 7 & $87 \%$ \\
3 & Good & & 1 & $13 \%$ \\
4 & Enough & & 0 & $0 \%$ \\
5 & Less & & 0 & $0 \%$ \\
6 & At least once & Total & 0 & $0 \%$ \\
\hline & & & $\mathbf{8}$ & $\mathbf{1 0 0 \%}$ \\
\hline
\end{tabular}

Based on the diagram above, it can be seen that the highest percentage value is $58 \%$ in the medium category and $42 \%$ for the high category.

Table 6. Percentage of Arm Reaction time of Female Karate Athletes of UKM Syiah Kuala University.

\begin{tabular}{lllcc}
\hline No & & Kategori & Frekuensi & Persentase \\
\hline 1 & Special & & 0 & $0 \%$ \\
2 & Very good & & 3 & $75 \%$ \\
3 & Good & & 1 & $25 \%$ \\
4 & Enough & & 0 & $0 \%$ \\
5 & Less & & 0 & $0 \%$ \\
6 & At least once & Total & 0 & $0 \%$ \\
\hline & & & $\mathbf{4}$ & $\mathbf{1 0 0 \%}$ \\
\hline
\end{tabular}

Based on the diagram above, it can be explained that the very good category is in the highest order with a percentage value of $75 \%$ then the good category is $25 \%$.

Table 7. Percentage of Leg Reaction time of Male Karate Athletes of UKM Syiah Kuala University.

\begin{tabular}{llccc}
\hline No & & Kategori & Frekuensi & Persentase \\
\hline 1 & Special & & 0 & $0 \%$ \\
2 & Very good & & 0 & $0 \%$ \\
3 & Good & & 8 & $100 \%$ \\
4 & Enough & & 0 & $0 \%$ \\
5 & Less & & 0 & $0 \%$ \\
6 & At least once & Total & 0 & $0 \%$ \\
\hline & & & & $\mathbf{8}$ \\
\hline
\end{tabular}

Based on Diagram it can be explained that the good category is in the highest order with a percentage value of $75 \%$ and achieved by all male athletes, totaling 8 athletes. 


\begin{tabular}{llccc}
\multicolumn{2}{l}{ Evaluation of Reaction Time on Karate Athletes UKM Syiah Kuala University } \\
\hline \multicolumn{1}{l}{ No } & Kategori & Frekuensi & Persentase \\
\hline 1 & Special & 0 & $0 \%$ \\
2 & Very good & 0 & $0 \%$ \\
3 & Good & 1 & $25 \%$ \\
4 & Enough & 2 & $50 \%$ \\
5 & Less & & 1 & $25 \%$ \\
6 & At least once & & 0 & $0 \%$ \\
\hline & & Total & $\mathbf{4}$ & $\mathbf{1 0 0 \%}$ \\
\hline
\end{tabular}

Based on Diagram 4.4, it can be explained that the sufficient category is in the highest order with a percentage value of $50 \%$, then good is $25 \%$ and less is $25 \%$.

\section{DISCUSSION}

Arm reaction time test on UKM karate athletes at Syiah Kuala University that for male athletes the excellent category is in the highest order with a percentage value of $87 \%$, then the good category is $13 \%$ and for female athletes the highest score is in the excellent category with a large percentage of $75 \%$, then good category with a percentage of $25 \%$. The limb reaction time test can be explained for male athletes that the good category is in the highest order with a percentage value of $100 \%$ in the good category, then for female athletes the highest score is in the sufficient category with a large percentage of $50 \%$, then good at $25 \%$ and less by $25 \%$. The results of the test show the ability of the UKM karate athletes to respond to the reactions given by the test through the light that comes out on the whole body reaction test. The tool shows the results of their body's response to a given reaction, and these results show their ability to win quickly. a given reaction (Hassan et al., 2017)

The reaction time of the arms and legs has an important role in the sport of karate in committee competition numbers. Success at the time of the committee number match is strongly influenced by the physical component. A good physical component and coupled with doing physical component training can improve optimal results in the field of sport that is occupied. In addition, success in committee number matches in karate is also influenced by the mastery of techniques in the sport. Movement techniques must start from basic movements to complex movements. Reaction time is the ability to perform similar movements in a row in the shortest possible time, or the ability to cover a distance in a fast time (Ismail et al., 2018)

This research is only limited to proving the theories that have been put forward by sports experts, however, this research is expected to be a meaningful input for the 
Evaluation of Reaction Time on Karate Athletes UKM Syiah Kuala University

development of science in general and more specifically for the development of sports science in order to improve the performance of the karate sport.(Matzenbacher et al., 2016).

\section{CONCLUSION}

Based on the results of research and data analysis on arm and leg reaction time test items using the whole body reaction time test on UKM karate athletes at Syiah Kuala University, the results obtained in the average value and percentage, it can be concluded as follows: 1 . Arm reaction time test with an average value of 0.169 seconds for male athletes and 0.173 seconds for female athletes. Furthermore, the highest percentage value is in the very good category, amounting to $87 \%$ for male athletes and for female athletes it is also in the very good category with a large percentage of $75 \%$. 2. The leg reaction time test the average value for male athletes is 0.269 seconds and for female athletes it is 0.361 seconds, with the highest percentage value for male athletes amounting to $100 \%$ in the good category, and for female athletes being in the sufficient category with a percentage of $50 \%$.

\section{REFERENCES}

Adi Saputra, S. (2020). Giakusuki Pada Karate: Analisis Peran Kekuatan Otot Lengan Dan Otot Bahu: Giakusuki On Karate: Analysis Of The Role Of Arm Strength And Shoulder Muscles. INSPIREE: Indonesian Sport Innovation Review, 1(1), 32-46. https://doi.org/10.53905/inspiree.v1i1.5

Ashar, B. (2020). Analisis Kemampuan Smash Bola Voli Dari Perspektif Daya Ledak Otot Tungkai Kaki Pada Atlet: Indonesisa. INSPIREE: Indonesian Sport Innovation Review, 1(2), 100-107. https://doi.org/10.53905/inspiree.v1i2.10

Botanists of the twenty-first century: Roles, challenges and opportunities. (n.d.). Retrieved September 3, 2021 from https://books.google.com/books/about/Botanists_of_the_twenty_first_century_r o.html?hl=id\&id=WXkuDAAAQBAJ

Creswell, J. W. (2002). Educational research: Planning, conducting, and evaluating quantitative and qualitative research. Merrill. 
Fajri, A. . (2020). Metode Drill Dalam Peningkatan Keterampilan Dasar Rolling

Senam Lantai: Drill Method In Improving Rolling Basic Skills for Gymnastics.

INSPIREE: Indonesian Sport Innovation Review, 1(1), 13-21. https://doi.org/10.53905/inspiree.v1i1.2

Hassan, H., Amir, M., \& Hossein, S. (2017). Confidence, Cognitive And Somatic Anxiety Among Elite And Non-Elite Futsal Players And Its Relationship With Situational Factors. Pedagogics, Psychology, Medical-Biological Problems of Physical Training and Sports, 21(2), 60-64. https://doi.org/10.15561/18189172.2017.0202

Hendra, H. (n.d.). Studi tingkat motivasi siswa dalam mengikuti kegiatan ekstrakurikuler bolavoli pada SMK Negeri 1 dan SMK Negeri 2.

Ismail, S. I., Nunome, H., Marzuki, F. F., \& Su'aidi, I. (2018). Measurement of Interaction between Futsal Footwear and Futsal Pitch Surface under Different Outsole Condition. Proceedings, 2(6), 233. https://doi.org/10.3390/proceedings2060233

Kuswari, M., Gifari, N. ., \& Himarwan, A. (2021). Effects of Aerobic Endurance Training vs HIIT on Energy Intake, Macronutrient Intake, and VO2Max Level on Fitness Centre Participants. INSPIREE: Indonesian Sport Innovation Review, 2(3), 186-193. https://doi.org/10.53905/inspiree.v2i3.48

Matzenbacher, F., Pasquarelli, B. N., Rabelo, F. N., Dourado, A. C., Durigan, J. Z., Rossi, H. G., \& Stanganelli, L. C. R. (2016). Adaptations in the physical capacities of U-18 futsal athletes during a competitive season. Brazilian Journal of Kinanthropometry and Human Performance, 18(1), 50-61. https://doi.org/10.5007/19800037.2016v18n1p50

Nauta, P. D., Omar, P.-L., Schade, A., \& Scheele, J. P. (n.d.). Accreditation Models in Higher Education. 67.

Pardilla, H. (2021). Physical Fitness and Learning Achievement Academic in Children Aged 10-12 years . INSPIREE: Indonesian Sport Innovation Review, 2(2), 165 of 175. https://doi.org/10.53905/inspiree.v2i2.51 
Qualitative Inquiry and Research Design. (n.d.). Retrieved September 3, 2021, from https://books.google.com/books/about/Qualitative_Inquiry_and_Research_Desig n.html?hl=id\&id=DLbBDQAAQBAJ

Sugiyono. (n.d.). Metode Penelitian Pendidikan (Pendekatan Kuantitatif, Kualitatif, dan R\&D) (p. Halaman 194). Alfabeta.

Tauhid, I., Aufan, R. ., \& Siregar, S. (2020). Upaya Meningkatkan Hasil Belajar Lari Sprint Melalui Pendekatan Bermain Pada Siswa Kelas VIII Sekolah Menengah Pertama: Indonesia. INSPIREE: Indonesian Sport Innovation Review, 1(3), 126-138. https://doi.org/10.53905/inspiree.v1i3.11

Tho Chandra, D., Syamsulrizal, S., Razali, R., \& Iqbal, M. (2021). Improving Front Rolling Learning Outcomes in Floor Gymnastics Learning Through Game Models: Meningkatkan Hasil Belajar Guling Depan Pada Pembelajaran Senam Lantai Melalui Model Permainan. INSPIREE: Indonesian Sport Innovation Review, 2(3), 194-203. https://doi.org/10.53905/inspiree.v2i3.50

Using international accreditation in higher education to effect changes in organisational culture: A case study from a Turkish university_lan Collins, 2015. (n.d.). Retrieved September 3, 2021, from https://journals.sagepub.com/doi/full/10.1177/1475240915592589 


\section{APPENDIX}

\section{Information About The Authors:}

\section{Syamsulrizal}

Email: syamsulrizal.jantho@unsyiah.ac.id; Department of Physical, Health and Recreation Education, Faculty of Teacher Training and Education, Universitas Syiah Kuala; Alamat: Jl. Teuku Nyak Arief No.441, Kopelma Darussalam, Kec. Syiah Kuala, Kota Banda Aceh, Aceh 23111.

\section{Teuku Riski Afrianda}

Email: teuku.riski96@gmail.com; Department of Physical, Health and Recreation Education, Faculty of Teacher Training and Education, Universitas Syiah Kuala; Alamat: Jl. Teuku Nyak Arief No.441, Kopelma Darussalam, Kec. Syiah Kuala, Kota Banda Aceh, Aceh 23111.

\section{Muhammad Iqbal}

Email: m_iqbal@stkipkusumanegara.ac.id; Orchid ID: https://orcid.org/0000-0002-97479374; Department of Physical Education and Sport, STKIP Kusuma Negara Jakarta; Alamat: Jl Raya Bogor Km. 24 Cijantung, Jakarta Timur, 13770. DKI Jakarta, Indonesia.

\section{Yeni Marlina}

Email: yenimarlinay@unsyiah.ac.id; Department of Physical, Health and Recreation Education, Faculty of Teacher Training and Education, Universitas Syiah Kuala; Alamat: Jl. Teuku Nyak Arief No.441, Kopelma Darussalam, Kec. Syiah Kuala, Kota Banda Aceh, Aceh 23111.

\section{Zahara}

Email: zahara@unsyiah.ac.id; Department of Physical, Health and Recreation Education, Faculty of Teacher Training and Education, Universitas Syiah Kuala; Alamat: Jl. Teuku Nyak Arief No.441, Kopelma Darussalam, Kec. Syiah Kuala, Kota Banda Aceh, Aceh 23111. 